\title{
Adult Diffuse Large Cell Lymphoma
}

National Cancer Institute

\section{Source}

National Cancer Institute. Adult Diffuse Large Cell Lymphoma. NCI Thesaurus. Code C7872.

A B-or T-cell non-Hodgkin lymphoma composed of a diffuse large cell lymphocytic infiltrate occurring in adults. 